\title{
Laparoscopic Versus Open Transperitoneal Nephrectomy for the Treatment of Giant Hydronephrosis
}

\author{
Dev Hidronefroz Tedavisinde Açığa Karşı Laparoskopik Transperitoneal Nefrektomi
}

\author{
(1) Çetin Demirdağ ${ }^{1}$, (1) Sinharib Çitgez ${ }^{1}$ \\ 1İstanbul University-Cerrahpaşa, Cerrahpaşa Faculty of Medicine, Department of Urology, Istanbul, Turkiye
}

What's known on the subject? and What does the study add?

Giant hydronephrosis is rare. In this study, the results were compared in patients treated with open and laparoscopic nephrectomy.

\begin{abstract}
Objective: To assess the effectiveness of laparoscopic transperitoneal nephrectomy in the treatment of patients with giant hydronephrosis and to compare the results with open nephrectomy.

Materials and Methods: We reviewed the data of 19 patients underwent laparoscopic (laparoscopic group, $n=8$ ) and open (open group, $n=11$ ) transperitoneal nephrectomy for giant hydronephrosis between January 2008 and 2018. Demographic characteristics, clinical, laboratory and radiological findings of cases were examined. Perioperative and postoperative outcomes were reported. Mann-Whitney U and Fisher's Exact tests were used in the statistical analysis.

Results: The mean operation time was 112.5 \pm 19.1 (90-140) minutes and 107.2 \pm 19.1 (80-140) minutes, respectively, for the laparoscopic and open groups ( $p=0.546)$. The mean hospitalization period was 3.5 (3-7) and $6(5-8)$ days, respectively, for the laparoscopic and open approach ( $p=0.003)$. No major complications during the perioperative period were observed in any of the patients. The mean follow-up periods were 36 (6-60) and 70 (39-80) months, respectively, for the laparoscopic and open groups $(p=0.000)$.

Conclusion: Laparoscopic transperitoneal nephrectomy appears to be equally effective to the open approach with a shorter hospitalization period for the treatment of giant hydronephrosis. It may be offered as a safe and acceptable model of treatment for patients presenting with giant hydronephrosis.
\end{abstract}

Keywords: Laparoscopy, Nephrectomy, Open, Giant, Hydronephrosis

\section{Öz}

Amaç: Bu çalışmada dev hidronefroz tespit edilen hastalarda transperitoneal laparoskopik nefrektominin etkinliğini değerlendirmeyi ve sonuçlarını açık nefrektomi yapılan hastalar ile karşılaştırmayı amaçladık.

Gereç ve Yöntem: Ocak 2008 ve 2018 tarihleri arasında dev hidronefroz için laparoskopik (laparoskopik grup, $n=8$ ) ve açık (açık grup, $n=11$ ) transperitoneal nefrektomi yapılan 19 hastanın verilerini gözden geçirdik. Olguların demografik özellikleri, klinik, laboratuvar ve radyolojik bulguları incelenmiştir. Perioperatif ve postoperatif sonuçlar bildirildi. İstatistiksel analizde Mann-Whitney U ve Fisher'in Kesin testleri kullanıldı.

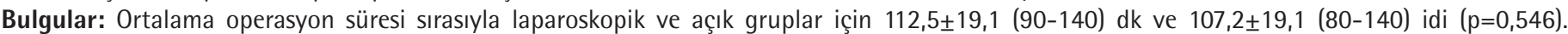
Ortalama yatış süresi laparoskopik ve açık yaklaşım için sırasıyla 3,5 (3-7) ve 6 (5-8) gündü $(p=0,003)$. Hiçbir hastada perioperatif majör komplikasyon izlenmedi. Laparoskopik ve açık gruplar için ortalama takip süreleri 36 (6-60) ve 70 (39-80) aydı (p=0,000).

Sonuç: Laparoskopik transperitoneal nefrektomi, dev hidronefrozun tedavisi için daha kısa hastanede yatış süresi ile açık yaklaşım kadar etkili görünmektedir. Dev hidronefroz ile başvuran hastalar için güvenli ve kabul edilebilir bir tedavi modeli olarak verilebilir.

Anahtar Kelimeler: Laparoskopi, Nefrektomi, Açık, Dev, Hidronefroz

Correspondence: Sinharib Çitgez MD, İstanbul University-Cerrahpaşa, Cerrahpaşa Faculty of Medicine, Department of Urology, İstanbul, Turkiye Phone: +90 5323122377 E-mail: drsinharib@yahoo.com ORCID-ID: orcid.org/0000-0002-3897-2951

Received: 03.01.2020

Accepted: 22.03.2020

Cite this article as: Demirdağ Ç, Çitgez S. Laparoscopic Versus Open Transperitoneal Nephrectomy for the Treatment of Giant Hydronephrosis. J Urol Surg 2020;7(4):276-280.

๑Copyright 2020 by the Association of Urological Surgery / Journal of Urological Surgery published by Galenos Publishing House. 


\section{Introduction}

Giant hydronephrosis is an uncommonly encountered entity. It is defined as excessive urine content in the renal pelvis more than one liter (1).

Common etiologies include ureteropelvic junction obstruction (UPJ), congenital abnormalities, or stones $(2,3)$.

Most of these kidneys are non-functioning at the time of diagnosis and nephrectomy is the treatment of choice in the majority of these cases (4). These poorly functioning kidneys often come to clinical attention as abdominal masses. Patients can also present with symptoms of nausea, vomiting, flank or abdominal pain, hematuria, and urinary tract infections $(4,5)$.

The general approach in the surgical treatment of giant hydronephrosis is nephrectomy (6). A wide range of treatment options are available ranging from conventional open surgery to minimally invasive approaches. There are increasing numbers of case reports in the literature demonstrating the feasibility of the laparoscopic approach as an alternative surgical treatment to conventional open surgical treatment of giant hydronephrosis. The reasons for this may be in particular due to the availability of experienced laparoscopic surgeons and higher numbers of laparoscopic surgeries being performed in urology clinics over the past few decades worldwide $(7,8)$. In this study, we aimed to present and compare the outcomes and complication rates of patients diagnosed with giant hydronephrosis of the kidney treated with either laparoscopic or open nephrectomies.

\section{Materials and Methods}

Between January 2008 and 2018 laparoscopic nephrectomy was performed in eight patients (laparoscopic group) and open nephrectomy (open group) in 11 patients with giant hydronephrosis. The etiology was congenital UPJ in six and nine patients who had undergone laparoscopic and open surgeries, respectively. As for the group of patients with ureterovesical junction (UVJ) obstruction one patient in the open group and two patients in the laparoscopic group had giant hydronephrosis. In addition one patient with giant hydronephrosis had ureteric calculi in the laparoscopic group. All cases in the laparoscopic group were successfully completed by laparoscopic procedure without the need for conversion to open approach.

The mean patient age was $30.6 \pm 9.1$ (25-52) and $31.2 \pm 7.7$ (26$54)$ years, respectively, for laparoscopic and open approaches ( $p=0.519$, Table 1). The mean body mass index was 25.9 (22.4$33.2)$ and $26.0(20.4-34.2) \mathrm{kg} / \mathrm{m}^{2}$, respectively, for laparoscopic and open approaches $(p=0.526)$. Renal function was normal in all patients. No patient had undergone previous abdominal surgery, except one patient who underwent contralateral pyeloplasty before laparoscopic nephrectomy.

Prior to surgery, patients underwent investigations including haemogram, and routine biochemical parameters, ultrasonography (US), computed tomography (CT) scan and renal dynamic scan. The scans were conducted to confirm that the kidneys were non-functioning (Figure 1). Postoperative complications were classified according to the Clavien Classification (9). Patients were evaluated by means of radiological and laboratory investigations during follow-up.

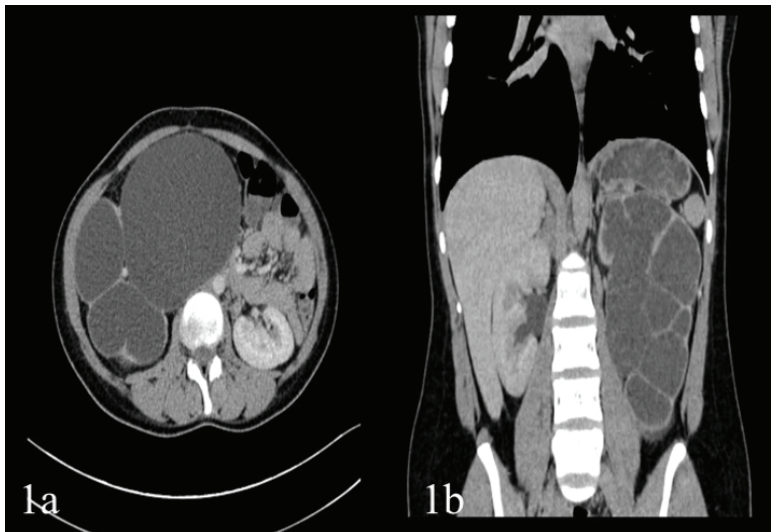

Figure 1. CT images of two patients with preoperative periods. (1A) The first patient's CT image at preoperative period demonstrated giant hydronephrosis in right kidney occupying the hemi-abdomen and displacing abdominal contents, transverse section. (1B) The second patient's CT image at preoperative period demonstrated giant hydronephrosis in left kidney, coronal section

CT: Computed tomography

Table 1. Patient characteristics

\begin{tabular}{|c|c|c|c|}
\hline & $\begin{array}{l}\text { Laparoscopic } \\
\text { group } \\
(\mathrm{n}=8)\end{array}$ & $\begin{array}{l}\text { Open group } \\
(n=11)\end{array}$ & p \\
\hline \multicolumn{4}{|c|}{ Age (year), mean \pm SD } \\
\hline Mean (range) & $\begin{array}{l}30.6 \pm 9.1 \\
(25-52)\end{array}$ & $\begin{array}{l}31.2 \pm 7.7 \\
(26-54)\end{array}$ & 0.519 \\
\hline \multicolumn{4}{|l|}{ Sex } \\
\hline Female & $3(37.5 \%)$ & $4(36.3 \%)$ & \multirow[t]{2}{*}{$>0.05$} \\
\hline Male & $5(62.5 \%)$ & $7(63.7 \%)$ & \\
\hline \multicolumn{4}{|l|}{ Side } \\
\hline Left kidney & $2(25.0 \%)$ & $3(27.3 \%)$ & \multirow[t]{2}{*}{$>0.05$} \\
\hline Right kidney & $6(75.0 \%)$ & $8(72.7 \%)$ & \\
\hline ASA score (mean) & 1 & 1 & $>0.05$ \\
\hline \multicolumn{4}{|l|}{ Clinical features } \\
\hline Pain & $6 / 8(75 \%)$ & $9 / 11(81.8 \%)$ & \multirow{3}{*}{0.745} \\
\hline Hematuria & $1 / 8(12.5 \%)$ & - & \\
\hline Urinary infection & $1 / 8(12.5 \%)$ & $2 / 11(18.2 \%)$ & \\
\hline \multicolumn{4}{|l|}{ Etiology } \\
\hline UPJ obstruction & $6 / 8(75 \%)$ & $9 / 11(81.8 \%)$ & \multirow{3}{*}{0.745} \\
\hline UVJ obstruction & $1 / 8(12.5 \%)$ & $2 / 11(18.2 \%)$ & \\
\hline Ureteral stone & $1 / 8(12.5 \%)$ & - & \\
\hline
\end{tabular}


This study was a retrospectively designed one, and all patients signed an informed consent agreement. Approval was given by the Ethical Committee of Istanbul University-Cerrahpasa, Cerrahpasa Medical Faculty of Medicine (IRB Number: 83045809-606.01.02).

\section{Statistical Analysis}

The Fisher Exact test was used for determining the difference between the categorical variables, while the Mann-Whitney $\mathrm{U}$ test was used for the identifying the difference between the means. The data was analyzed with the Statistical Package for the Social Sciences v. 16 (SPSS Inc, Illinois, USA). A p-value under 0.05 was considered statistically significant.

\section{Surgical Technique}

The patients who underwent laparoscopic nephrectomy for giant hydronephrosis were placed in the right or left modified flank positions suitable for transperitoneal approaches. The first trocar positioned at the lateral side of the rectus muscle at the level of umbilicus on coronal section was inserted by open (Hasson) technique and a controlled pneumoperitoneum was created. This approach was performed to avoid injury to the readily displaced abdominal contents. Other trocars were placed under direct vision. Later, an $18-\mathrm{G}$ and $20 \mathrm{~cm}$ needle was inserted into the kidney and a certain amount of urine was aspirated in order to achieve the necessary space for medialization of the bowel, and to achieve an easier dissection. Just as the colon was reflected medially, the kidney was completely decompressed, and the renal hilum was identified. The kidney was involuted to its minimum volume and removed via the smallest incision possible. The ureter was ligated or clipped. The artery and veins were individually clipped and nephrectomy was completed. In the open group, standard transperitoneal nephrectomy was performed.

\section{Results}

We performed laparoscopic transperitoneal nephrectomy in eight patients and open nephrectomy in 11 patients with giant hydronephrosis. Six of the patients presented with pain, one of them with hematuria and one with urinary infection, in the laparoscopic approach. In the open approach, nine patients presented with pain while two presented with urinary infection. All procedures in the laparoscopic group were completed laparoscopically without a need for conversion to open surgery.
The mean operation time was $112.5 \pm 19.1$ (90-140) minutes and 107.2 \pm 19.1 (80-140) minutes, respectively, for laparoscopic and open groups ( $p=0.546$, Table 2 ). The hospitalization period was $3.5(3-7)$ and 6 (5-8) days, respectively, for laparoscopic and open approaches $(p=0.003)$. No perioperative complications were observed in any of the patients. The mean blood loss was measured at $130 \pm 17.5(90-140) \mathrm{mL}$ and $130 \pm 14.6(90-145) \mathrm{mL}$, respectively for laparoscopic and open groups ( $p=0.781$, Table 3 ). Hemoglobin $(\mathrm{g} / \mathrm{dL})$ and creatinine $(\mathrm{mg} / \mathrm{dL})$ levels were measured at $13.2 \pm 1.6$ and $0.86 \pm 0.2$ respectively, for the laparoscopic approach and $13.1 \pm 1.4$ and $0.83 \pm 0.2$ for the open approach, respectively in the postoperative period while these levels were $15.0 \pm 1.8$ and $0.83 \pm 0.3$ for the laparoscopic approach and $14.8 \pm 1.5$ and $0.82 \pm 0.2$, respectively for the open approach in the preoperative period and there was no statistically significant difference ( $p=0.932$ and 0.873 , respectively). Postoperative complications were seen in two of eight patients $(25 \%)$ in the laparoscopic group and two of 11 patients (18.2\%) in the open group ( $p>0.05$ ). Postoperatively, one patient each in both the laparoscopic and open groups developed high fever categorized as a Grade 1 complication according to the Clavien classification. Also after the laparoscopic and open interventions; paralytic ileus which is considered a Grade 2 complication occurred in two of the patients who had undergone corresponding operations. These patients recovered after medical treatment and followup procedures. During the follow-up, patients were evaluated based on laboratory tests and radiological findings (US or CT).

\begin{tabular}{|c|c|c|c|}
\hline & $\begin{array}{l}\text { Laparoscopic } \\
\text { group } \\
(n=8)\end{array}$ & $\begin{array}{l}\text { Open } \\
\text { group } \\
(n=11)\end{array}$ & $\mathbf{p}$ \\
\hline \multicolumn{3}{|l|}{ Operation time (min) } & \multirow[t]{2}{*}{0.546} \\
\hline Mean \pm SD (range) & $\begin{array}{l}112.5 \pm 19.1 \\
(90-140)\end{array}$ & $\begin{array}{l}107.2 \pm 19.1 \\
(80-140)\end{array}$ & \\
\hline \multicolumn{3}{|l|}{ Bleeding $(\mathrm{mL})$} & \multirow[t]{2}{*}{0.781} \\
\hline Mean \pm SD (range) & $\begin{array}{l}130 \pm 17.5 \\
(90-140)\end{array}$ & $\begin{array}{l}130 \pm 14.6 \\
(90-145)\end{array}$ & \\
\hline $\begin{array}{l}\text { Postoperative complications } \\
\text { according to Clavien } \\
\text { Classification }\end{array}$ & $2(25.0 \%)$ & $2(18.2 \%)$ & \multirow[t]{3}{*}{$>0.05$} \\
\hline Grade 1 & $1(12.5 \%)$ & $1(9.1 \%)$ & \\
\hline Grade 2 & $1(12.5 \%)$ & $1(9.1 \%)$ & \\
\hline \multicolumn{3}{|l|}{ Hospitalization time (days) } & \multirow[t]{2}{*}{0.003} \\
\hline Mean (range) & $3.5(3-7)$ & $6(5-8)$ & \\
\hline
\end{tabular}

Table 3. Perioperative and postoperative levels of hemoglobin and creatinine

\begin{tabular}{|c|c|c|c|c|c|}
\hline & \multicolumn{2}{|l|}{ Preoperative } & \multicolumn{2}{|l|}{ Postoperative } & \multirow[b]{2}{*}{$p$} \\
\hline & Laparoscopic approach & Open approach & Laparoscopic approach & Open approach & \\
\hline Haemoglobin level & $15.0 \pm 1.8$ & $14.8 \pm 1.5$ & $13.2 \pm 1.6$ & $13.1 \pm 1.4$ & $0.932^{*}$ \\
\hline Creatinine level & $0.83 \pm 0.3$ & $0.82 \pm 0.2$ & $0.86 \pm 0.2$ & $0.83 \pm 0.2$ & $0.873^{*}$ \\
\hline
\end{tabular}


During the average follow-up period of 36 (6-60) and 70 (39$80)$ months for laparoscopic and open approaches, none of the patients had any complications. Only one patient (9.1\%) died because of cardiac disease during the follow-up period, in the open group.

\section{Discussion}

The definition of giant hydronephrosis is the presence of more than $1,000 \mathrm{~mL}$ or $1.6 \%$ of body weight of fluid in the collecting system $(5,10)$. Giant hydronephrosis may present with urinary tract infection, renal insufficiency or gross hematuria following trauma in adults (4). However, patients usually remain asymptomatic until the late stages, because this condition is usually slowly progressive $(4,5)$. Abdominal US, CT and magnetic resonance images are helpful in the differential diagnosis $(4,11)$. Giant hydronephrosis has been treated by various procedures such as pyeloplasty, nephrectomy, or percutaneous nephrostomy placement. Preservation of renal parenchyma is the primary aim during management (3). Nephrectomy is preferred if there is no improvement in renal function. Laparoscopic nephrectomy for giant hydronephrosis has been reported in a few studies $(4,7,8)$. We performed laparoscopic transperitoneal nephrectomy for giant hydronephrosis in eight patients and open nephrectomy in 11 patients, in this study. Laparoscopic approach was successfully completed in all of our patients in the laparoscopic group and no intraoperative complications were observed in either group.

Laparoscopic nephrectomy in patients with giant hydronephrosis is expected to be more challenging than laparoscopic nephrectomy in patients with other benign lesions. To overcome this difficulty, it may be necessary to fabricate a number of modifications. Challacombe et al. (7) have described a number of technical modifications to perform laparoscopic nephrectomy in patients with giant hydronephrosis. Technical modifications to facilitate laparoscopic surgery included initial fingerplasty, balloon dissection in two directions, initial intact dissection, subsequent pelvic puncturing and aspiration, and extracorporeal retraction if necessary. They compared these giant hydronephrosis patients with another group of patients who underwent laparoscopic nephrectomy for benign diseases. They concluded the study stating that blood loss was greater and the operation time was longer than the other (benign diseases) group. Similarly, we performed some technical maneuvers including early aspiration and after drainage of the urine, the kidney size was involuted, and the operating space was made more comfortable and we achieved a more clear visualization of the anatomy and performed the operation under better conditions. Additionally, it was easier to dissect the kidney from the surrounding tissues. The mean operation time of the cases were $112.5 \pm 19.1$ (90-140) minutes and 107.2 \pm 19.1 (80-140) minutes and the mean blood loss was measured at
$130 \pm 17.5$ (90-140) $\mathrm{mL}$ and $130 \pm 14.6(90-145) \mathrm{mL}$, respectively, in the laparoscopic and open groups. There was no statistically significant difference between two groups $(p=0.546$ and $p=0.781$, respectively). These results were similar to the other studies found in literature $(4,7,8)$.

All patients in the present series either had a non-functioning kidney or a kidney contributing less than 10\% of total renal function. We demonstrated the status of renal function via renal scintigraphy. All of the patients in this series were symptomatic. Late complications of giant hydronephrosis include infection, pain and rupture. For this reason, even if patients are asymptomatic, surgical treatment may be required. However, conservative management is one of the options for giant hydronephrosis, especially in elderly patients. Patients may be followed up at regular intervals with urine culture and radiologic imaging such as US or CT $(7,8)$. Six of the patients in the laparoscopic group and nine in the open group presented with pain, one patient in the laparoscopic group with hematuria and one patient in the laparoscopic group and two of the patients in the open group with urinary infections in our series. The etiology was congenital UPJ in six patients in the laparoscopic group and nine patients in the open group. UVJ obstruction was noted in one of the patients in the laparoscopic group and two of the patients in the open group. Also ureteral calculi were identified in one of the patients in the laparoscopic group. In the open approach, secondary urinary infection was observed in two patients and a nephrostomy tube was inserted to provide decompression concomitantly. Also, the nephrostomy tubes of these patients remained intact until surgery.

Laparoscopic nephrectomy can be performed with a transperitoneal approach or retroperitoneal approach. There are certain notable advantages of the retroperitoneal approach over transperitoneal approach such as; the risk of injury to intraperitoneal organs is lower. Furthermore, the risk of developing intraperitoneal adhesions is lower. However, the retroperitoneal approach also has certain disadvantages. The most important disadvantage is the limited amount of surgical space available. If we are to cite from the literature, the study published by Hemal et al. (4) focusing on this subject would be a suitable example. In their study laparoscopic nephrectomy was performed using a transperitoneal approach in large hydronephrotic kidneys. The authors emphasized that due to the large hydronephrotic kidneys, the available void in the retroperitoneum is considerably reduced. However, over time their surgical experience with the retroperitoneal approach has improved, and they have successfully performed laparoscopic retroperitoneal nephrectomy in large hydronephrotic kidneys. In the series, the last 12 patients were operated using a retroperitoneal approach and no complications were encountered. In conclusion, we believe that the option of a 
laparoscopic approach for the nephrectomy depends on the preference and the individual training of each surgeon. We routinely used transperitoneal approaches for laparoscopic surgeries in our clinic. Although we have no experience with a retroperitoneal approach, we did not encounter any perioperative complications in our cases with transperitoneal approach. However, the limited number of patients may have reflected in the low complication rates causing bias for the laparoscopic group, in this study. Also, there was no statistically significant difference between the laparoscopic and open groups in terms of complication rates in our study ( $p>0.05)$.

Laparoscopic nephrectomy is the gold standard treatment method that is used safely in both benign and malignant renal diseases. Open nephrectomy is also an option for these diseases. However, as with all other transperitoneal surgeries, there is also a risk of developing complications following laparoscopic or open transperitoneal nephrectomies. For example, paralytic ileus may develop following colonic mobilization during transperitoneal laparoscopic or open nephrectomies. Development of ileus delayed oral intake in our patients in this study. In the retroperitoneal approach, complications related to bowel adhesions and port hernia pose a lower risk. In our study, postoperative complications were seen in cases belonging to both laparoscopic and open groups. Postoperatively, one of the patients in each group developed high fever which is categorized as a Grade 1 complication according to the Clavien classification. Also after the laparoscopic and open interventions; paralytic ileus which is considered a Grade 2 complication occurred in two of the patients who had undergone corresponding operations. These patients recovered after medical treatment during the follow-up process.

\section{Study Limitations}

In this study, we reported the outcomes of the patients who underwent laparoscopic and open transperitoneal nephrectomy for giant hydronephrosis. The findings of this study suggest that laparoscopic transperitoneal nephrectomy is technically feasible in patients with giant hydronephrosis and results were found to be similar to the open nephrectomy group. However, our study has several limitations. The data were collected longitudinally and verified retrospectively, which could have introduced an element of error. Another limitation of our study was that the number of patients was limited. Despite these limitations, our results suggest that modified laparoscopic transperitoneal nephrectomy is as safe as open nephrectomy treatment in the management of giant hydronephrosis. Further prospectively designed studies should be undertaken to overcome these limitations.

\section{Conclusion}

Laparoscopic transperitoneal nephrectomy seems to be a feasible procedure similar to open nephrectomy with shorter hospitalization period for the treatment of giant hydronephrosis. There is a need for comparative and prospectively designed studies involving larger patient series.

\section{Ethics}

Ethics Committee Approval: Approval was given by the Ethical Committee of Istanbul University-Cerrahpasa, Cerrahpasa Medical Faculty of Medicine (IRB Number: 83045809-606.01.02).

Informed Consent: Consent form was filled out by all participants.

Peer-review: Externally peer-reviewed.

Authorship Contributions:

Surgical and Medical Practices: S.Ç., Ç.D., Concept: S.Ç., Ç.D., Design: S.Ç., Ç.D., Data Collection or Processing: Ç.D., S.Ç., Analysis or Interpretation: S.Ç., Ç.D., Literature Search: S.Ç., Ç.D., Writing: S.Ç., Ç.D.

Conflict of Interest: No conflict of interest was declared by the authors.

Financial Disclosure: The authors declared that this study received no financial support.

\section{References}

1. Hinman F Jr, Oppenheimer RO, Katz IL. Accelerated obstruction at the ureteropelvic junction in adults. J Urol 1983;129:812-815.

2. Wang QF, Zeng G, Zhong L, Li QL, Che XY, Jiang T, Zhang ZW, Zheng W, Tang $\mathrm{OZ}$, Chen F, Wang KN. Giant hydronephrosis due to ureteropelvic junction obstruction: A rare case report, and a review of the literature. Mol Clin Oncol 2016;5:19-22.

3. Sokhal AK, Agrawal M, Saini DK, Singh K, Gupta AK, Sankhwar S, Pal Singh B. Giant hydronephrotic kidney masquerading as urinoma: A rare presentation with review of literature. Urol Case Rep 2017;13:69-71.

4. Hemal AK, Wadhwa SN, Kumar M, Gupta NP. Transperitoneal laparoscopic nephrectomy for giant hydronephrosis. J Urol 1999;162:35-39.

5. Chiang $\mathrm{PH}$, Chen MT, Chou $\mathrm{YH}$, Chiang $\mathrm{CP}$, Huang $\mathrm{CH}$, Chien $\mathrm{CH}$. Giant hydronephrosis: report of 4 cases with review of the literature. J Formos Med Assoc 1990;89:811-817.

6. Ansari MS, Singh I, and Hemal AK. Giant hydronephrotic kidney mimicking intestinal obstruction. Int Urol Nephrol 2003;35:319-320.

7. Challacombe B, Sahai A, Murphy D, Dasgupta P. Laparoscopic retroperitoneal nephrectomy for giant hydronephrosis: when simple nephrectomy isn't simple. J Endourol 2007;21:437-440.

8. Alharbi B. Transperitoneal laparoscopic nephrectomy for giant hydronephrotic non-functioning kidney. Urol Case Rep 2018;21:110-112.

9. Dindo D, Demartines N, Clavien PA. Classification of surgical complications: a new proposal with evaluation in a cohort of 6336 patients and results of a survey. Ann Surg 2004;240:205-213.

10. Tazi MF, Riyach O, Ahallal Y, Mellas S, Khallouk A, El Fassi MJ, Farih MH. Giant Urinary Bladder and Bilateral Giant Hydronephrosis due to Bladder Neck Obstruction: One Case Report and Literature Review. Case Rep Urol 2012;2012:817519.

11. Fukasawa M, Kobayashi H, Matsushita K, Araki I, Takeda M. Intraperitoneal rupture of giant hydronephrosis due to ureteral cancer accompanied by renal cell carcinoma. J Urol 2002;167:1393-1394. 